\title{
Reproducibility of Sterilized Rubber Impressions
}

\author{
Khalid M. Abdelaziz ${ }^{1}$ \\ Ahmed M. Hassan ${ }^{1}$ \\ J.S. Hodges ${ }^{2}$ \\ ${ }^{1}$ Department of Dental Materials, Faculty of Dentistry, Mansoura University, Mansoura, DK, Egypt \\ ${ }^{2}$ Division of Biostatistics and School of Dentistry, University of Minnesota, Minneapolis, MN, USA
}

\begin{abstract}
Impressions, dentures and other dental appliances may be contaminated with oral micro-flora or other organisms of varying pathogenicity from patient's saliva and blood. Several approaches have been tried to control the transmission of infectious organisms via dental impressions and because disinfection is less effective and has several drawbacks for impression characterization, several sterilization methods have been suggested. This study evaluated the reproducibility of rubber impressions after sterilization by different methods. Dimensional accuracy and wettability of two rubber impression materials (vinyl polysiloxane and polyether) were evaluated after sterilization by each of three well-known methods (immersion in $2 \%$ glutaraldehyde for $10 \mathrm{~h}$, autoclaving and microwave radiation). Non-sterilized impressions served as control. The effect of the tray material on impression accuracy and the effect of topical surfactant on the wettability were also evaluated. One-way ANOVA with Dunnett's method was used for statistical analysis. All sterilizing methods reduced the reproducibility of rubber impressions, although not always significantly. Microwave sterilization had a small effect on both accuracy and wettability. The greater effects of the other methods could usually be overcome by using ceramic trays and by spraying impression surfaces with surfactant before pouring the gypsum mix. There was one exception: glutaraldehyde still degraded dimensional accuracy even with ceramic trays and surfactant. We conclude that a) sterilization of rubber impressions made on acrylic trays was usually associated with a degree of dimensional change; b) microwave energy seems to be a suitable technique for sterilizing rubber impressions; c) topical surfactant application helped restore wettability of sterilized impressions.
\end{abstract}

Key Words: impressions, sterilization, wettability, trays, dimensional changes.

\section{INTRODUCTION}

Dental professionals are normally exposed either directly or indirectly to a wide variety of microorganisms during routine practice (1). Several items such as impressions, dental appliances and others are often heavily contaminated with microorganisms from saliva and blood. These contaminants should be thoroughly removed prior to performing further work, however retention of oral microbes on impression surfaces is expected and could persist during the ensuing period (2-4).

One study (5) revealed that washing impressions sometimes does not clear away all the saliva and blood contaminants, and it may be necessary to remove these with a very soft brush. Dentists and paradental staff have become aware of the importance of controlling microbial transmission (6). Impression disinfection is believed to be one of the simplest methods of control, however this process is less effective on pathogens than any type of sterilization because it is intended to kill disease-producing microorganisms but not bacterial spores, which can be killed only by sterilization techniques $(7,8)$. At the same time, sterilization of certain types of impressions by the use of common techniques is also considered unacceptable $(9,10)$.

Accordingly, a recent approach of sterilization by microwave radiation has been used for sterilizing some dental appliances and instruments (11-13). However, this technique has not yet been tried for impression sterilization. This study evaluated the dimensional accuracy and the wettability of rubber impressions after sterilization with different techniques including microwave energy.

\section{MATERIAL AND METHODS}

Customized impressions made from both vinyl 
polysiloxane (Cinch Platinum, Parkell, Farmingdale, NY, USA) and polyether (Impregum F, 3M ESPE AG Dental Products, Seefeld, Germany) rubber impression materials were evaluated and were divided into four groups according to the type of sterilization received.

Group I: Impressions were immersed in 2\% glutaraldehyde solution (Septocide, Chemical Industries Development, Giza, Egypt) for $8 \mathrm{~h}$.

Group II: Impressions were sterilized in an autoclave (Stericlave $15 \mathrm{H}$, Cominox, Biassono, MI, Italy) at $115^{\circ} \mathrm{C}$ under 1.5 bar pressure.

Group III: Impressions were sterilized using microwave energy (Goldstar, MA-680SE, $2450 \mathrm{MHz}$, Seoul, Korea) at high power for $10 \mathrm{~min}$ as recommended by Rohrer and Bulard (14).

Group IV (Control): No sterilization was used.

\section{Testing Dimensional Accuracy}

A detail reproduction test block, with two horizontal grooves running perpendicular to the main three grooves that were $0.025,0.050$ and $0.075 \mathrm{~mm}$ wide (ADA Specification no. 19), was used as the master die. Impressions of that die were made in customized acrylic and porcelain trays to form two distinct subgroups, each composed of five impressions. Dimensional changes of either sterilized or non-sterilized impressions were measured as shown in Figure 1, using a digital caliper (Mitutoyo Solar, Model CD-S6"CP, Mitutoyo Corp., Japan).

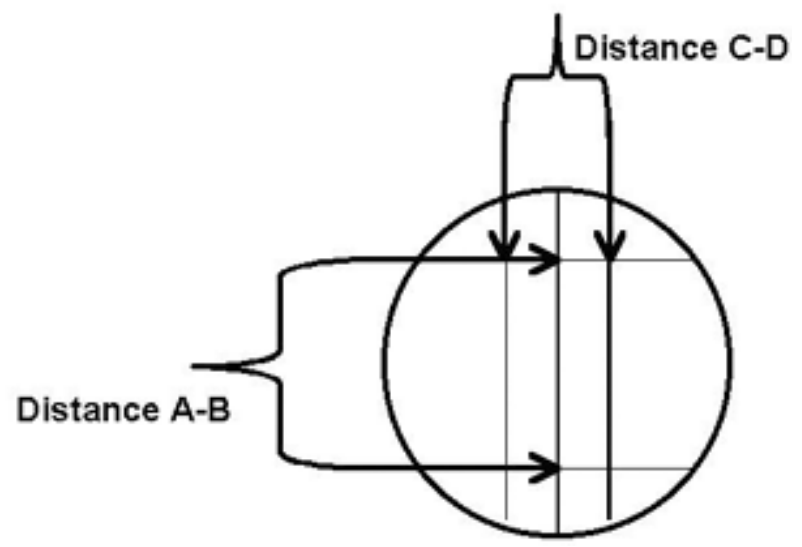

Figure 1. Measured distances. The vertical arrow shows the A-B distance, and the horizontal arrow shows the C-D distance.

\section{Testing Wettability}

Wettability of the sterilized impression surfaces was evaluated in simulation of the normal practice situation, pouring gypsum slurry against impression surfaces rather than the use of calcium sulfate solution. Flat impression surfaces ( $10 \times 6 \times 0.2 \mathrm{~cm}$ each) were made and half of them (one impression for each group) were sprayed with Lubrofilm surfactant (Dentaurum, Pforzheim, Ispringen, Germany) after sterilization.

Equal amounts ( $2 \mathrm{ml}$ each) of mixed dental stone (Zeta Hardenal, Industria Zingardi, Novi Ligure, AL, Italy) were then dispensed over impression surfaces while vibrating (at high speed for $5 \mathrm{~s}$ ) to form five equal sized patties. After setting of the stone patties, each was released from the impression and sectioned using a saw.

The contact angles of dental stone made with the impression surface were then measured. The crosssections of one half of each sectioned patty were viewed using a stereomicroscope (Olympus PM- PB20, Shinjuku-ku, Tokyo, Japan) and the images were captured and printed. The contact angles represented by the cross-sectional edges of each stone patty were then measured by the use of a protractor (Figure 2).

\section{Statistical Analysis}

For both dimensional accuracy and contact angle measurements, one-way analysis of variance (ANOVA) was used to test the differences among the eight tested subgroups. Non-sterilized impressions made in acrylic trays and those poured without receiving any surface treatment were the control groups for dimensional accuracy and for wettability, respectively. Dunnett's posthoc test was used to indicate which specific subgroups differed significantly from the control. Significance was defined as $\mathrm{p}<0.05$.

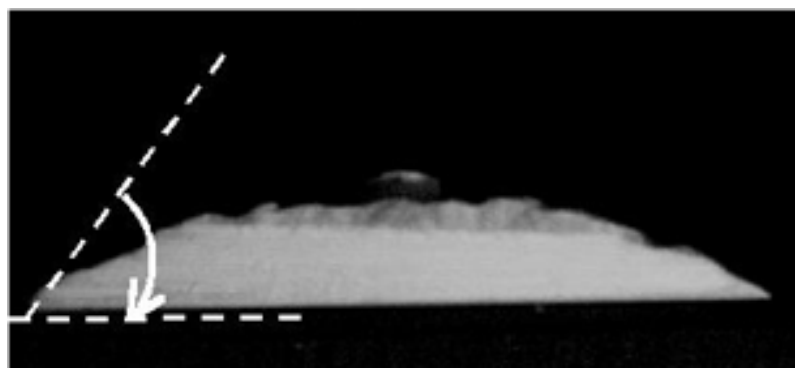

Figure 2. Measuring the contact angle. 


\section{RESULTS}

Figures 3-6 represent the results of analysis. Dimensional accuracy differed significantly among the tested groups for both types of dental impression material (ANOVA, $p<0.0001$ ). This difference was found to be significant (as indicated by Dunnett's test) for impressions sterilized by immersion in $2 \%$ glutaraldehyde solution, in addition to vinyl polysiloxane impressions sterilized by autoclave and made in acrylic trays (Figures 3 and 4). At the same time, using ceramic trays did help in the reduction of the rates of dimensional changes in comparison to acrylic trays.

Data for the wettability testing revealed a difference among the tested groups of both types of impression material either treated with topical surfactant or not (ANOVA, $\mathrm{p}<0.0001$ ). Figures 5 and 6 show that sterilizing both types of impressions by autoclave or by immersion in the glutaraldehyde solution resulted in significantly higher contact angle measurements. How-

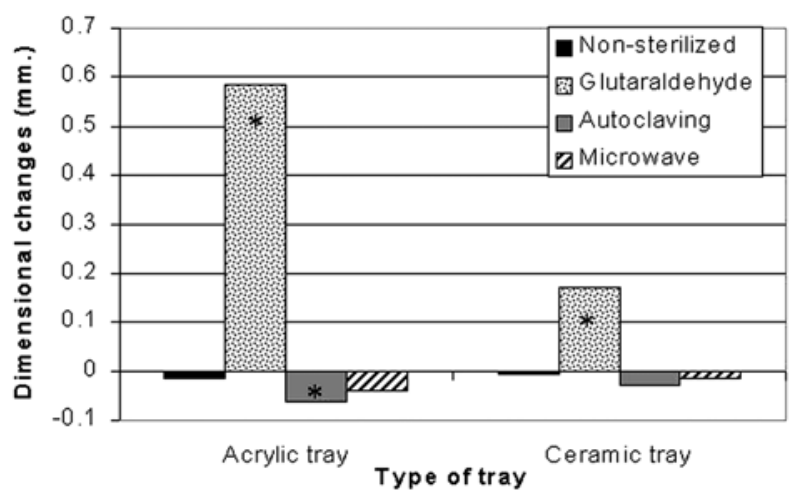

Figure 3. Dimensional changes of sterilized vinyl polysiloxane impressions. *Significantly different from control.

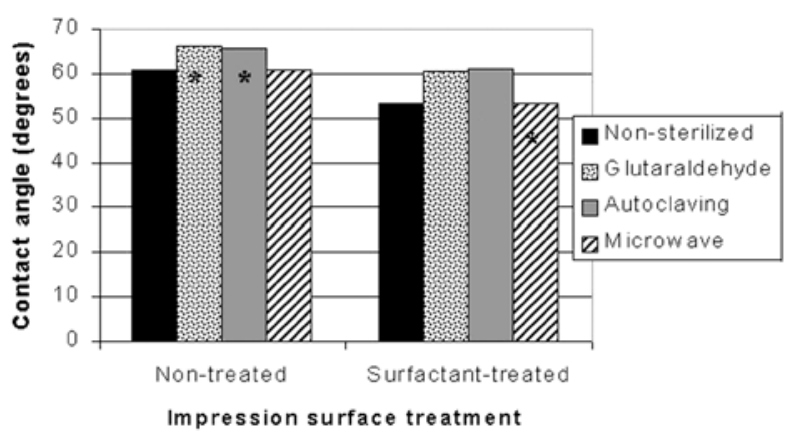

Figure 5. Wettability of sterilized vinyl polysiloxane impressions. *Significantly different from control. ever, using the topical surfactant before pouring the gypsum decreased its contact angle with the surface of both impression materials, so that they were either insignificantly different from or significantly lower than the control group.

It is also clear from these figures that only impressions sterilized by microwave have no significant deleterious differences from the non-sterilized impressions (control) under any of the conditions of this study.

\section{DISCUSSION}

Because disinfection is a less lethal process, impression sterilization is considered very important in an infection control program. One study indicated that autoclave sterilization is not an acceptable method (10) while others suggest wet sterilization using a glutaraldehyde solution $(15,16)$. However, microwave energy as an alternative approach for impression sterilization has not been evaluated.

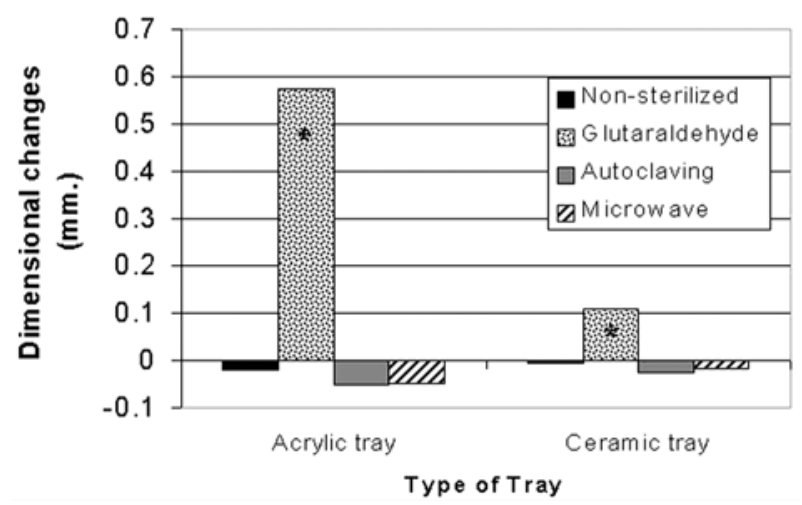

Figure 4. Dimensional changes of sterilized polyether impressions. *Significantly different from control.

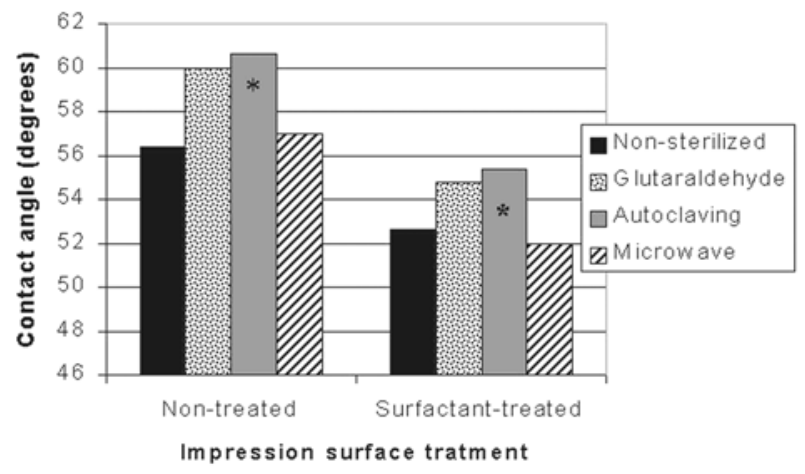

Figure 6. Wettability of sterilized polyether impressions. *Significantly different from control. 
In the present study, the use of microwave energy for sterilizing the rubber impressions had no significant effect on their dimensional accuracy. Due to the possible warpage of acrylic trays as a result of microwave radiation, the recorded change is reduced by using ceramic trays instead of acrylic ones. Also, all impressions showed a minimal contraction except those sterilized by immersion in $2 \%$ glutaraldehyde solution, which showed modest expansion using either the ceramic or acrylic trays. This finding agrees with that of Rios et al. (16) and could be explained by some fluid uptake by the impression materials. The recorded expansion values were for acrylic trays because the tray material is able to absorb and adsorb some of the immersing fluid besides the amount imbibed by the impression itself.

Both the surface tension of liquid (presented by gypsum slurry) and the surface energy of solid (presented by impression surfaces) control the contact angle measurement (17). Wet heating of the impression in an autoclave as well as immersion in glutaraldehyde may alter their surface energy leading to higher gypsum/ impression contact angle measurements. On the other hand, topical application of a surfactant may cause a decrease in the surface tension of the gypsum slurry when brought into contact with the impression surface, leading to a reduction in the contact angle readings and better flow of gypsum over the sterilized impression surfaces (18).

Our results showed that sterilization of rubber impressions made on acrylic trays is usually associated with a degree of dimensional change; however this inaccuracy can be decreased by the use of ceramic trays; the use of microwave energy for sterilizing rubber impressions seems to be a suitable technique; topical surfactant application helps in restoring the wettability of sterilized impressions.

\section{RESUMO}

Moldes, dentaduras e outros dispositivos odontológicos podem estar contaminados com a microflora oral ou outros microorganismos de patogenicidade variada do sangue ou saliva de pacientes. O controle da transmissão de infecção por meio de moldes tem sido tentado de diversas maneiras e, uma vez que a desinfecção é menos eficaz e apresenta muitos obstáculos para moldagens, vários métodos de esterilização têm sido propostos. Este estudo avaliou a reprodutibilidade de moldes de borracha após a esterilização por diferentes métodos. A estabilidade dimensional e molhabilidade de dois materiais de moldagem (polisiloxano de vinil e poliéter) foram avaliadas após esterilização por três métodos bastante conhecidos (imersão em glutaraldeído $2 \%$ por $10 \mathrm{~h}$, autoclavagem e radiação por microondas). Moldes não-esterilizados foram usados como controle. $\mathrm{O}$ efeito do material da moldeira na precisão da moldagem e o efeito de surfatante tópico na molhabilidade também foram avaliados. ANOVA com método Dunnett foram usados para análise estatística. Todos os métodos de esterilização reduziram a reprodutibilidade das moldagens, porém nem sempre esta redução foi significante. A esterilização por microondas teve pequeno efeito na estabilidade e molhabilidade. Os maiores efeitos dos outros métodos puderam ser eliminados utilizando-se moldeiras de cerâmica e borrifando as superfícies dos moldes com surfatante antes de vazar o gesso. Houve uma exceção: o glutaraldeído diminuiu a estabilidade dimensional mesmo com o uso de moldeiras de cerâmica e surfatante. Concluiu-se que a esterilização dos moldes de borracha obtidos com moldeiras de acrílico esteve geralmente associada a certo grau de alteração dimensional. Energia de microondas parece ser uma técnica eficaz para esterilizar moldagens de borracha. A aplicação tópica de surfatantes ajudou a restaurar a molhabilidade de modelos esterilizados.

\section{ACKNOWLEDGEMENTS}

This research was presented at the 80th IADR/AADR/CADR meeting, San Diego, 2002. Supported in part by NIDCR P30DE09737.

\section{REFERENCES}

1. Westerholm HS, Bradley DV, Schwartz RS. Efficacy of various spray disinfectants on irreversible hydrocolloid impressions. Int $\mathrm{J}$ Prosthdont 1992;5:47-53.

2. Verran J, Kossar S, McCord JF. Microbiology study of selected risk areas in dental technology laboratories. J Dent 1996;24:7780.

3. Powell GL, Runnells RD, Saxon BA, Whisenant BK. The presence and identification of organisms transmitted to dental laboratories. J Prosthet Dent 1990;64:235-237.

4. Samaranayake LP, Hunjan M, Jennings KJ. Carriage of oral flora on irreversible hydrocolloid and elastomeric impression materials. J Prosthet Dent 1991;65:244-249.

5. Rowe AHR, Forrest JO. Dental impressions, the probability of contamination and a method of disinfection. Br Dent $\mathrm{J}$ 1978; 19:184-186.

6. ADA Council on Scientific Affairs and ADA Council on Dental Practice. Infection control recommendations for the dental office and the dental laboratory. J Am Dent Assoc 1996;127:672-680.

7. Gleason MJ, Molinari A. Antiseptics and disinfectants in pharmacology and therapeutics for dentistry. 4th edn. St. Louis, Baltimore, London: Mosby Company, 1998.

8. Miller CH. Sterilization and disinfection: what every dentist needs to know. J Am Dent Assoc 1992;123:46-54.

9. Holtan JR, Olin PS, Rudney JD. Dimensional stability of polyvinylsiloxane impression material following ethylene oxide and steam sterilization. J Prosthet Dent 1991;65:519-525.

10. Olin PS, Rudney JD, Breitbach RS, Holtan JR. The effect of sterilization on addition silicone impressions in custom and stock metal trays. J Prosthet Dent 1994;71:625-630. 
11. Tate WH, Goldschmidt M, Ward M, Grant RL. Disinfection and sterilization of composite polishing instruments. Am J Dent 1995;8:270-272.

12. Dixon DL, Breeding LC, Faler TA. Microwave disinfection of denture base materials colonized with Candida albicans. J Prosthet Dent 1999;81:207-214.

13. Baysan A, Whiley R, Wright PS. Use of microwave energy to disinfect long-term soft lining materials contaminated with Candida albicans or Staphylococcus aureus. J Prosthet Dent 1998;79:454-458.

14. Rohrer MD, Bulard RA. Microwave sterilization. J Am Dent Assoc 1985;110:194-198.
15. Langenwalter EM, Aquilino SA, Turner KA. The dimensional stability of elastomeric impression materials following disinfection. J Prosth Dent 1990;63:270-276.

16. Rios MP, Morgano SM, Stein RS, Rose L. Effects of chemical disinfectant solution on the stability and accuracy of the dental impression complex. J Prosthet Dent 1996;76:356-362.

17. Soderholm K. (Contributor). Phillips' Science of Dental Materials. 10th edn. Philadelphia, London, Tokyo, WB Saunders Company, 1996. p 26-28.

18 Millar BJ, Dunne SM, Robinson PB. An in vivo study of a clinical surfactant used with poly(vinyl siloxane) impression materials. Quintessence Int 1996;27:707-709. 